\title{
The Organizational Citizenship Behaviors and Organizational Commitments of Organizational Members Influences the Effects of Organizational Learning
}

\author{
Chang, Chi-Cheng, Tsai, Meng-Chen, Tsai, Meng-Shan
}

\begin{abstract}
The purposes of the study were to examine the relationship among organizational citizenship behaviors, organizational commitments and organizational learning effects. The researchers employ person-organization fit (P-O fit) to as the theoretical background. The researchers delivery 200 questionnaires to 12 companies; the final response rate is $\mathbf{5 2 . 5 \%}$ $(105 / 200)$. In this study, the researchers used SEM to test three hypotheses about organizational citizenship behaviors, organizational commitments and organizational learning effects. The results of the research include that organizational citizenship behaviors and organizational commitments influence organizational learning effects positively, and organizational citizenship behaviors can be influenced positively by organizational commitments.
\end{abstract}

Index Terms-component; organizational citizenship behaviors,;organizational commitments; organizational learning

\section{INTRODUCTION}

The aims of this study are therefore threefold: (1) we want to explore the meaning and character of the organizational citizenship behaviors in this study; (2) we want to ensure the meaning and character of the organizational commitments in this study; (3) we want to examine that the organizational citizenship behaviors and the organizational commitments influence the organizational learning positive. The primary research questions to be addressed in this study are as follows: (1) what are the meaning and character of the organizational citizenship behaviors in this study? (2) What are the meaning and character of o organizational commitments? (3)How do organizational citizenship behaviors and the organizational commitments influence the organizational learning?

\section{RESEARCH BACKGROUND}

In recently years, organizational learning is getting considerable attentions; a part is the strategy of organizational learning which as well as regarding each industrial influence research [1]. One research provides the

Chang, Chi-Cheng, Tsai, Meng-Chen, Tsai, Meng-Shan are Department of Technology Application and Human Resource Development National Taiwan Normal University Taipei, Taiwan

e-mail:supercarydbt@yahoo.com.tw relationship between organizational learning and organizational performance [2].

Recently, there is one study [3] discusses the issue that the harmful communicational pattern among the members of the organization will impact on the organizational performance. There are $66 \%$ members of the organization mention that when they suffer the impolite treat will decrease their performance; the $80 \%$ members of the organization note that they always spend time to cope with the impolite treat; the $78 \%$ members of the organizational proposes that they don't to work hard to implement the plan of organization when they suffer the impolite treat. To sum up, the poor communicational pattern will organization failed.

No studies directly state that the communicational pattern among the members of the organization will influence the effects of organizational learning, but communicational pattern will affect the performance of organization [3]. Owing to organizational performance is closely related to the organizational learning, and communicational pattern may influence the performance of organization probably.

The different opinions about organizational citizenship behaviors and organizational commitments of organizational members exist between employees and organization. If organization or enterprises have good commitments to organizational members, and the employees of organization will have loyalty to their organization. Similarly, the members display sufficient organizational citizenship behaviors to their organization; the organization will treat their members well.

There are a lot of studies which emphasize on the relationship between the organizational citizenship behaviors with organizational commitments, but we have not found the study about the organizational citizenshipbehaviors and organizational commitments influences the effects of organizational learning. So, we want to study the organizational citizenship behaviors and organizational commitments of organizational members influences the effects of organizational learning.

\section{THEORETICAL BACKGROUND}

In this study, researchers consider person-organization fit (P-O fit) as the theoretical background. P-O fit refers to the compatibility between people and organization. Furthermore, 
P-O fit embraces three concepts: (1) complementary fit; (2) supplementary fit, as well as (3) both. Complementary fit means that at least one entity offers what the other demand. Supplementary fit can be defined as that they share similar fundamental features. And, P-O fit shows the degree of match between the individual characteristics of employees and the attributions of job $[4,5]$. Additionally, the views of $\mathrm{P}-\mathrm{O}$ fit refer to judgments of congruence between individual values of employees and the culture of an organization. Therefore, employees possess the values match the values of organizations and the members belong to the organizations, employees ought to engage in the broader mission of the organizations. Moreover, the perceptions of $\mathrm{P}-\mathrm{O}$ fit should be associated with citizenship behaviors. And the result in a research demonstrates that the significantly correlation exists between P-O fit and peer-rated citizenship behaviors [6]. In the present research, personal variable is organizational citizenship behavior; organizational commitment and organizational learning belong to the field of organizational variable. What's more, the researchers want to realize the relationship among the three variables.

\section{ORGANIZATIONAL CITIZENSHIP BEHAVIORS}

\section{A. The meaning of organizational citizenship behaviors}

Sangmook defined organizational citizenship behaviors (OCB) are viewed widely as contributing to an organization's overall effectiveness [7]. In addition, OCB refers to "those organizationally beneficial behaviors and gestures that can neither be enforced on the basis of formal role obligations nor elicited by contractual guarantee of recompense."[8]

In an organizational context, OCB is often part of an informal psychological contract in which the employee hopes that such extra effort may be perceived and then rewarded by the boss and the organization [9]

\section{B. The characters of organizational citizenship behaviors}

In the present study, researchers reveal four distinct elements constituting the concept of OCB.

1) Altruism is a type of discretionary behavior consisting of behaviors that help a specific other person [10] and motivate employees to assist other employees to deal with their problems of works whereas courtesy is also discretionary behavior not to create work-related problems with others [11].

2) Conscientiousness indicates the discretionary extra-role behaviors that exceed the requirements of the task, job, as well as work ethics [11].

3) Sportsmanship can be defined as any behavior demonstrating tolerance of less than ideal circumstances without complaining [10]. Sportsmanship of employees is to tolerate circumstances and unexpected or less preferable without complaining [11].

4) Civic virtue is one kind of behavior and the employees participate in organizational practices with the concern of the life of the company [11]. Civic virtue means a macro-level interest in or commitment to the whole organization [10].

\section{ORgANIZATIONAL COMMITMENTS}

\section{A. The meaning of organizational commitments}

Steven and Brian defined organizational commitment as the relative strength of an individual's identification and involvement in a particular organization [12]. On the other hand, Organizational commitment refers and focuses on the attachment, emotionally and functionally $[13,14]$.

\section{$B$. The characters of organizational commitments}

Three general themes in attitudinal conceptualizations of organizational commitment contain affective commitment (AC), continuance commitment (CC), and normative commitment (NC) [15]. And the three-dimensional construct is defined as follows [16]:

1) The affective commitment refers to the employee's emotional attachment to, identification with, and involvement in, the organization. The affective commitment represents the emotional attachment that an employee feels toward the employing firm.

2) The continuance commitment refers to commitment based on the costs that the employee associates with leaving the organization. Lawrence and William [17] also demonstrate that the continuance commitment represents an attachment to the organization, but represents the perceived costs to the employee of leaving the firm.

3) The normative commitment refers to the employee's feelings of obligation to remain with the organization. And researchers of one study indicate that commitment was related to job involvement and job satisfaction [18].

\section{ORGANIZATIONAL LEARNING}

\section{A. The meaning of organizational learning}

Victor assumed that organizational learning means the capability of one company to maintain and promote performance and interests [19]. Organizational learning focuses on four questions: (1) who learns? (2) How do they learn? (3) When do they learn? (4) Why do they learn? [20]

\section{B. The characters of organizational learning}

Micaela reported that organizational learning contain four constructs, which are information acquisition, information distribution, information interpretation, and information memory [21].

1) Information acquisition: the employers of the corporations encourage their employees to distribute the information about business.

2) Information distribution: the employees transfer the acquired knowledge at an individual level each other.

3) Information interpretation: it included four elements: (1) knowledge is translated, (2) developing models of understanding, (3) bringing out meaning, and (4) assembling conceptual schemes among key managers.

4) Information memory: organization collected knowledge and information; used theory; and shared mental model, database, procedures, routines, and guide behaviors. 


\section{RESEARCH HYPOTHESES}

\section{A. The organizational citizenship behaviors and the effects of organizational learning}

Anit and Anat [22] proposed a conclusion, which reveals that organizational citizenship behavior is related to organizational learning. According to the above statement, we suggest the first hypothesis as follows:

H1. The organizational citizenship behaviors positively influence the effects of organizational learning.

\section{B. The organizational commitments and the effects of organizational learning}

There have been several references discussing about the impact of organizational learning on commitment [23]. One study argues that organizational learning is able to predict organizational commitment [24]. The other research also reveals that the relationship exist between organizational commitments and organizational learning [25]. As a consequence, we propose the second hypothesis as follows:

H2. The organizational commitments learning positively influence the effects of organizational learning.

\section{The organizational citizenship behaviors and the organizational commitments}

The most frequently identified significance of OCB are that organizational commitments and organizational commitments have been found to predict organizational citizenship behaviors [26]. The research focusing on the organizational commitment has an impact on the organizational citizenship behavior [27]. In one study, a meta-analysis has shown that OCB correlated with organizational commitment [28]. In the other research, organizational commitment was positively related to OCB [29]. Based on the above descriptions, we provide the third hypothesis as follows:

H3. The organizational commitments positively influence organizational citizenship behaviors.

\section{DATA COLlection AND SAMPlE}

We collect data from 12 companies in the north, the central, and the south of Taiwan for this study. There are 3 companies in north, 6 companies in central and 3 companies in south. The samples come from these companies, and the employees of the corporations had accepted our requirements, the range of the quantity of employees from 10 to 130 , moreover, the respondents include the mangers and staffs. The quantity of total questionnaires we delivered is 200 , and the final response rate was $52.5 \%(105 / 200)$.

\section{Statistical Analysis Of Data}

In this study, the researchers employ SPSS 15.0 and Amos 7.0 to carry out the statistic and analyze the data which come from respondents. We used SPSS to implement the factor analysis, and reliability and applied Amos to complete CFA of SEM.

\section{The Research Structure}

The structure of research is the relationship with the organizational citizenship behaviors, organizational commitments, and organizational learning. There are four components of the organizational citizenship behaviors, which are altruism, conscientiousness, sportsmanship and civic virtue; the three elements of the organizational commitments are affective, continuance and normative; and the four factors of the organizational learning are information acquisition, and information distribution, information interpretation, information memory. The research structure of this study is showed in Figure. 1.

\section{MEASURES}

This study is a quantitative study; data was collected using a scale survey instrument. In the present study, first, we use the OCB scales of [30-32] to measure OCB. Second, we employ OCQ (organizational commitment questionnaire) [33] to examine organizational commitment. Finally, we take advantage of the research of [21] to understand the characteristic of organizational learning.

We will use these scale to investigate the participants, and test the relationship among the variables. All constructs were measured with a four point Likert scale. We measured them with 50 items using the scale: organizational citizenship behavior contains 19 items, organizational commitment is 15 items, and organizational learning includes 16 items.

\section{Reliability And Valibity Of The Measures}

The validity of the measures used factor analysis to explore the loading of 50 items. The loading of all items' are above 0.3 . So, no items should be deleted. The reliability of the 11 constructs measured by Cronbach $\alpha$. In terms of OCB, there were 0.702 for altruism, 0.662 for civic virtue, 0.603 for sportsmanship, as well as 0.645 for conscientiousness. 


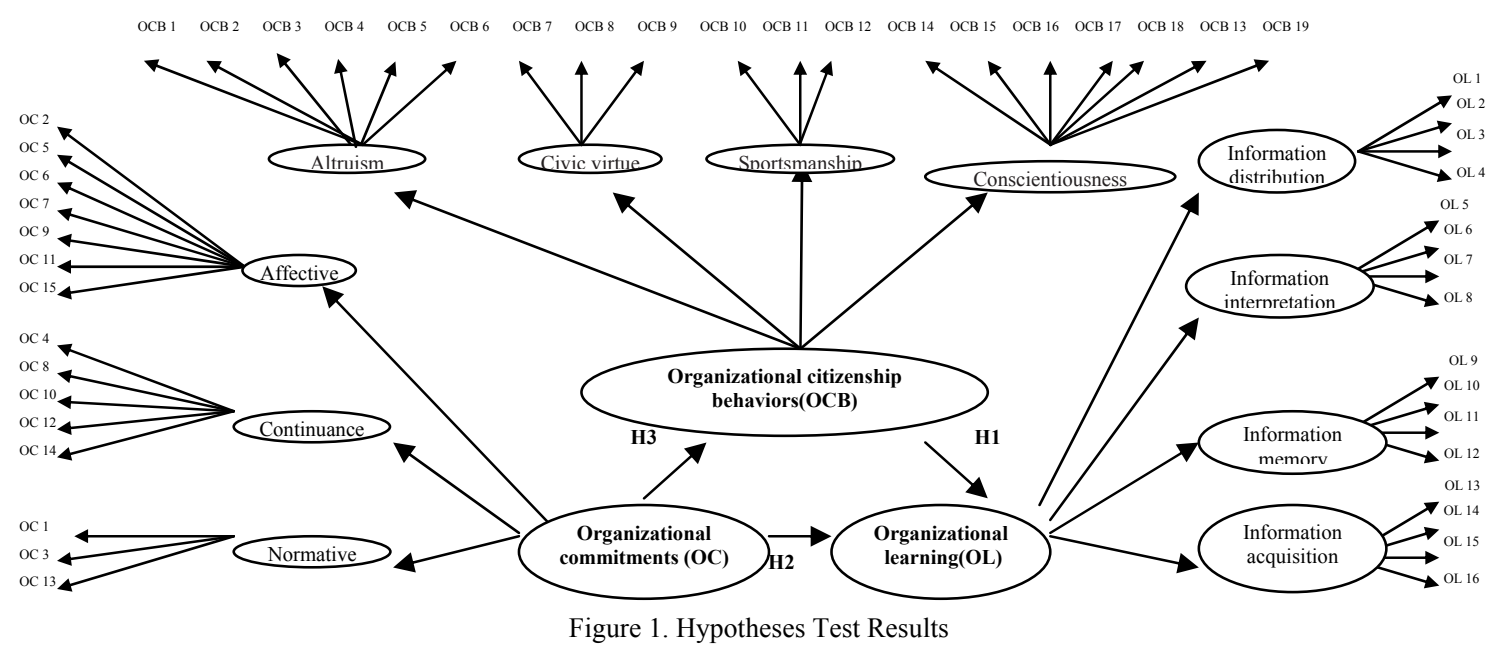

So far as OC category is concerned, there were 0.743 for affective, 0.815 for continuance, 0.760 for normative. Our study revealed 0.723 for information distribution, 0.632 for Information interpretation, 0.833 for information memory, and 0.819 for information acquisition in aspects about OL.

On the contrary, in the prior research, in terms of OCB, Scott et al. [30] reported the Cronbach $\alpha$ coefficients of 0.88 for their altruism, 0.73 for their civic virtue and 0.70 for their sportsmanship, and Carmen et al. [32] revealed 0.771 for their conscientiousness. Lawrence and William [17] reported the Cronbach $\alpha$ coefficients of 0.83 for their affective; Ajay, Sabir, and Cary [34] showed 0.84 for their continuance and 0.73 for their normative in OC aspect. In the OL category, Micaela and Daniel [21] reported the Cronbach $\alpha$ coefficients of 0.83 for information distribution, 0.80 for information interpretation, 0.87 for information memory, and 0.8 for information acquisition. In a word, our Cronbach $\alpha$. coefficients are similar to the previous study.

\section{CONFIRMATORY FACTOR ANALYSIS}

The researchers of this study used second-order confirmatory factor analysis in order to assess each construct. The second-order confirmatory factor analysis of the organizational citizenship behaviors was showed in TABLE I ; the second-order confirmatory factor analysis of the organizational commitments was showed in TABLE $I$, and the second-order confirmatory factor analysis of the organizational commitments was showed in TABLEIII.

\section{Results Of Path ANAlysis}

SEM methodology was employed to test the hypotheses in this research. The model (Figure 1) summarizes three hypotheses which are related to organizational citizenship behaviors, organizational commitments and organizational learning.

\section{Hypotheses Test Results}

The results of testing the hypotheses are presented in the TABLE IV. The TABLE IV showed the detailed information related to constructs. In terms of 3 hypotheses, the results for
H1 (OCB > OL, $\mathrm{p}<0.01)$ can present the evidence to support the concept that organizational citizenship behaviors positively influence the effects of organizational learning. Additionally, we support $\mathrm{H} 2$ (OCB $>\mathrm{OL}, \mathrm{p}<0.01$ ), and it refers that the organizational commitments learning positively influence the effects of organizational learning. Likewise, regarding $\mathrm{H} 3(\mathrm{OC}>\mathrm{OCB}, \mathrm{p}<0.05)$, it indicates that the organizational commitments positively influence organizational citizenship behaviors, and H3 is supported.

\section{DISCUSSION}

According to the results of TABLE IV, we have three findings :(1) the organizational citizenship behaviors positively influence the effects of organizational learning; (2) the organizational commitments positively influence the effects of organizational learning, and (3) the organizational commitments positively influence organizational citizenship behaviors. The three findings support the three hypotheses of the study and are in line with previous studies.

First, we can understand that if the employees of an organization have the organizational commitments to their organization, and they could process organizational learning well. Owing to the organizational commitments, employees identify with organization's culture, objective, and value, and they want to learn any abilities, skills, and knowledge in order to achieve the goal of organization. Second, if the staff has good organizational citizenship behaviors, they also could process organizational learning well since the staff has organizational citizenship behaviors are influenced by the organizational commitments positively. When the staff is loyal to their organization, they can make more commitments to help the organization to complete organization's strategies.

To sum up, the effects of organizational learning are influenced by the organizational citizenship behaviors and the organizational commitments positively. The organizational commitments can positively influence organizational citizenship behaviors.

TABLE I . SECOND-ORDER CONFIRMATORY FACTOR ANALYSIS OF THE ORGANIZATIONAL CITIZENSHIP BEHAVIORS

\begin{tabular}{|c|c|c|c|}
\hline \multirow{2}{*}{$\begin{array}{c}\text { First-order } \\
\text { construct }\end{array}$} & \multicolumn{2}{|c|}{ First-order } & \multirow{2}{*}{$\begin{array}{c}\text { Second- } \\
\text { order }\end{array}$} \\
\hline & Indicator & Loading & \\
\hline
\end{tabular}




\begin{tabular}{|c|c|c|c|}
\hline \multirow[t]{6}{*}{ Altruism } & OCB01 & 0.702 & \multirow[t]{6}{*}{0.762} \\
\hline & OCB02 & 0.654 & \\
\hline & ОСВ03 & 0.689 & \\
\hline & OCB04 & 0.708 & \\
\hline & OCB05 & 0.619 & \\
\hline & OCB06 & 0.493 & \\
\hline \multirow[t]{3}{*}{ Civic virtue } & OCB07 & 0.724 & \multirow[t]{3}{*}{0.814} \\
\hline & OCB08 & 0.613 & \\
\hline & ОСВ09 & 0.678 & \\
\hline \multirow{4}{*}{$\begin{array}{l}\text { Sportsman- } \\
\text { ship }\end{array}$} & OCB10 & 0.654 & \multirow[t]{4}{*}{0.725} \\
\hline & OCB11 & 0.582 & \\
\hline & OCB12 & 0.632 & \\
\hline & OCB13 & 0.708 & \\
\hline \multirow{6}{*}{$\begin{array}{l}\text { Conscienti- } \\
\text { ousness }\end{array}$} & OCB14 & 0.548 & \multirow[t]{6}{*}{0.676} \\
\hline & OCB15 & 0.761 & \\
\hline & OCB16 & 0.818 & \\
\hline & OCB17 & 0.596 & \\
\hline & OCB18 & 0.723 & \\
\hline & OCB19 & 0.675 & \\
\hline
\end{tabular}

TABLE II . SECOND-ORDER CONFIRMATORY FACTOR ANALYSIS OF THE ORGANIZATIONAL COMMITMENTS

\begin{tabular}{cccc}
\hline First-order & \multicolumn{2}{c}{ First-order } & Second-order \\
\cline { 2 - 4 } construct & Indicator & Loading & Loading \\
\hline Affective & OC11 & 0.400 & 0.540 \\
& OC05 & 0.584 & \\
& OC02 & 0.739 & \\
& OC07 & 0.109 & \\
& OC09 & 0.406 & \\
& OC15 & 0.500 & \\
Continuance & OC06 & 0.762 & \\
& OC04 & 0.692 & 0.886 \\
& OC12 & 0.641 & \\
& OC14 & 0.716 & \\
& OC10 & 0.746 & \\
Normative & OC08 & 0.708 & \multirow{2}{*}{ OC01 } \\
& OC03 & 0.585 & 0.745 \\
& OC13 & 0.672 & \\
\hline
\end{tabular}

Fit statistics for measurement model of 19 items for 4 constructs: $\chi_{(0)}^{2}=0.000 ; \mathrm{CFI}=1.000 ; \mathrm{NFI}=1.000 ; \mathrm{IFI}=1.000$

TABLEIII. SECOND-ORDER CONFIRMATORY FACTOR ANALYSIS OF THE ORGANIZATIONAL LEARNING

\begin{tabular}{cccc}
\hline \multirow{2}{*}{$\begin{array}{c}\text { First-order } \\
\text { construct }\end{array}$} & \multicolumn{2}{c}{ First-order } & Second-order \\
\cline { 2 - 4 } Information & OL01 & Loading & Loading \\
distribution & OL02 & 0.529 & 0.730 \\
& OL03 & 0.594 & \\
& OL04 & 0.674 & \\
Information & OL05 & 0.693 & 0.842 \\
interpretation & OL06 & 0.575 & \\
& OL07 & 0.634 & \\
& OL08 & 0.366 & \\
Information & OL09 & 0.524 & 0.816 \\
memory & OL10 & 0.693 & \\
& OL11 & 0.770 & \\
Information & OL12 & 0.775 & \\
acquisition & OL13 & 0.806 & 0.878 \\
& OL14 & 0.736 & \\
& OL15 & 0.524 & \\
& OL16 & 0.783 & \\
\hline
\end{tabular}

Fit statistics for measurement model of 19 items for 4 constructs: $\chi_{(2)}^{2}=6.257$; $\mathrm{CFI}=0.974 ; \mathrm{NFI}=0.963 ; \mathrm{IFI}=0.975$

TABLE IV CONSTRUCT STRUCTURAL MODEL

\begin{tabular}{|c|c|c|c|}
\hline \multirow{2}{*}{$\begin{array}{c}\text { Linkages in } \\
\text { the Model }\end{array}$} & \multicolumn{2}{|c|}{ Hypotheses } & \multirow{2}{*}{$\begin{array}{c}\text { Standardized } \\
\text { Parameter } \\
\text { Estimates } \\
\text { Estimate } \\
\end{array}$} \\
\hline & Number & Sign & \\
\hline \multicolumn{4}{|l|}{ Hypothesis } \\
\hline $\mathrm{OCB}->\mathrm{OL}$ & H1 & + & $0.236^{* *}$ \\
\hline $\mathrm{OC}->\mathrm{OL}$ & $\mathrm{H} 2$ & + & $0.660^{* * *}$ \\
\hline $\mathrm{OL}->\mathrm{OCB}$ & $\mathrm{H} 3$ & + & $0.794^{* * *}$ \\
\hline
\end{tabular}

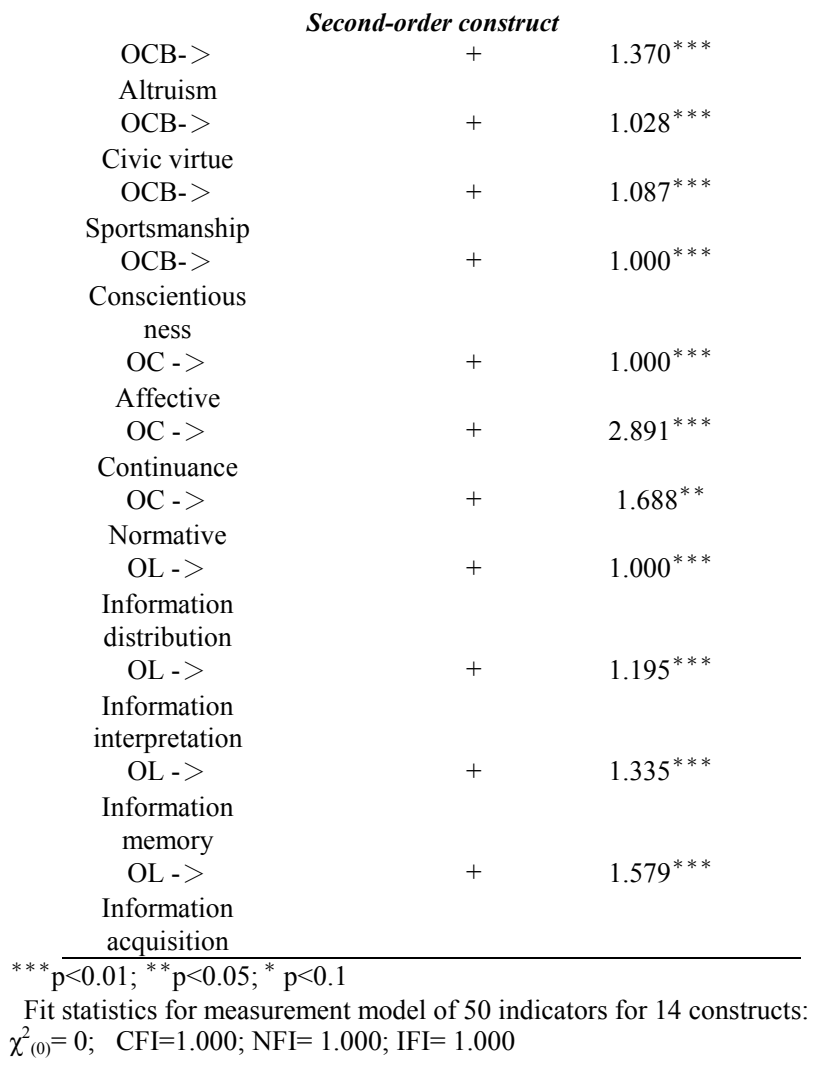

\section{CONCLUSIONS}

In the study, we used SEM to examine the three hypotheses, and we confirm all of them. First, there are sufficient evidence to prove that organizational learning can be influenced positively by organizational citizenship behaviors and organizational commitments. If the employees have higher willingness to organizational citizenship behaviors or organizational commitments, and the company can have higher quality of organizational learning.

On the other hand, we also verify the third hypotheses that organizational citizenship behaviors can be influenced positively by organizational commitments. These results lead to the conclusion that when the manager of an organization provides their staff with high organizational commitments, as well as the higher quality of organizational commitments results in the employees' organizational citizenship behaviors very well.

The anterior researches reveal that the organizational citizenship behaviors is related to organizational learning [22] and the relationship exist between organizational commitments and organizational learning [25]. Compared with the previous research, this study has verified that organizational citizenship behaviors and organizational commitments can positively influence organizational learning.

The research area is the organizational members' organizational citizenship behaviors and organizational commitments in the workplace. The limitations of the present research are the hidden reasons of organizational citizenship behaviors and organizational commitments.

To sum up, organizational citizenship behaviors, organizational commitments, and organizational learning are the fairly critical elements to managers and employees of an 
organization. Thus, the different viewpoints between managers and employees to the organizational citizenship behaviors, moreover, organizational commitments and organizational learning can be measured in future studies.

\section{REFERENCES}

[1] S.-C. Fang and J.-F. Wang, "Effects of Organizational Culture and Learning on Manufacturing Strategy Selection: An Empirical Study," International Journal of Management, vol. 23, pp. 503-514, 2006.

[2] M. L. Santos-Vijande, M. J. Sanzo-Pérez, L. I. Álvarez-González, and R. Vázquez-Casielles, "Organizational learning and market orientation: interface and effects on performance," Industrial Marketing Management, vol. 34, pp. 187-202, 2005.

[3] C. Porath and C. Pearson, "How Toxic Colleagues Corrode Performance," Harvard Business Review, vol. 32, pp. 1-135, 2009.

[4] [4] H.-T. Chang, N.-W. Chi and A. Chuang, "Exploring the Moderating Roles of Perceived Person-Job Fit and Person-Organisation Fit on the Relationship between Training Investment and Knowledge Workers' Turnover Intentions," Applied Psychology, vol. 59, pp. 566-593, 2010.

[5] C. J. Resick, B. B. Baltes and C. W. Shantz, "Person-organization fit and work-related attitudes and decisions: Examining interactive effects with job fit and conscientiousness," Journal of Applied Psychology, vol. 92, pp. 1446-1455, 2007.

[6] D. M. Cable and D. S. DeRue, "The convergent and discriminant validity of subjective fit perceptions," Journal of Applied Psychology, vol. 87, pp. 875-884, 2002.

[7] K. Sangmook, "Public service motivation and organizational citizenship behavior in Korea," International Journal of Manpower, vol. 27 , pp. 722-740, 2006

[8] O. Izhar, "Organizational citizenship behavior in teaching: The consequences for teachers, pupils, and the school," International Journal of Educational, vol. 23, pp. 375-389, 2009.

[9] C. Dhitiporn and C. D. Brooklyn, "The effects of internal career orientations on organizational citizenship behavior in Thailand," Career Development International, vol. 9, pp. 406-423, 2004.

[10] T. Omer and K. Umut, "Materialistic attitude as an antecedent of organizational citizenship behavior," Management Research News, vol. 30, pp. 581-596, 2007

[11] Y. J. Joo and H. Soonkwan, "Organizational citizenship behaviour (OCB), TQM and performance at the maquiladora," International Journal of Quality \& Reliability Management, vol. 25, pp. 793-808, 2008.

[12] P. Steven and P. Brian, "A management development model: Measuring organizational commitment and its impact on job satisfaction among executives in a learning organization," Journal of Management Development, vol. 26, pp. 353-369, 2007.

[13] E. Dov and K. Meni, "Values and organizational commitment," International Journal of Manpower, vol. 22, pp. 593-599, 2001.

[14] K. S. Lawson and D. S. Paul, "Employee wellbeing, control and organizational commitment," Leadership \& Organization Development Journal, vol. 30, pp. 256-273, 1996.

[15] B. Birgit, "Disentangling organizational commitment: The dangers of the OCQ for research and policy," Personnel Review, vol. 26, pp. 114-131, 1996.

[16] S. Lynn, "Antecedents and consequences of organizational commitment to accounting organizations," Managerial Auditing Journal, vol. 19, pp. 945-955, 2004.

[17] P. K. Lawrence and J. C. William, "Organizational commitment and auditors in public accounting," Managerial Auditing Journal, vol. 22, pp. 354-375, 2007.

[18] K. Ayse, I. C. Emre and I. Sezgin, "Path analysis of organizational commitment, job involvement and job satisfaction in Turkish hospitality industry," Tourism Review,, vol. 64, pp. 4-16, 2009.

[19] J. G. Victor, J. L. Francisco and J. V. Antonio, "Influence of personal mastery on organizational performance through organizational learning and innovation in large firms and SMEs," Technovation, vol. 27, pp. 547-568, 2007.

[20] M. Huysman, "Rethinking organizational learning: analyzing learning processes of information system designers," Accting., Mgmt. \& Info. Tech, vol. 10, pp. 81-99, 2000

[21] M. C. Micaela and J. J. Daniel, "The Effectiveness of TQM : The Key Role of Organizational Learning in Small Businesses," International Small Business Journal, vol. 27, pp. 98-125, 2009.
[22] S. Anit and D. Anat, "Exploring organizational citizenship behaviors from an organizational perspective: The relationship between organizational learning and organizational citizenship behaviors," Journal of Occupational and Organizational Psychology, vol. 77, pp. 281-298, 2004.

[23] K. Vijay and C. Andrea, "Employee perceptions of organizational learning as determinants of affective commitment in knowledge intensive firms," presented at the Academy of Human Resource Development International Research Conference, Panama City, FL, 2008.

[24] J. Bhatnagar, "Predictors of organizational commitment in India: strategic HR roles, organizational learning capability and psychological empowerment," The International Journal of Human Resource Management, vol. 18, pp. 1782-1812, 2007.

[25] D. Alessia and H. Regina, "Learning orientation, organizational commitment and talent retention across generations: A study of European managers," Journal of Managerial Psychology, vol. 23, pp. 929-953, 2008.

[26] S. D. Zoe, "The influence of service climate and job involvement on customer-oriented organizational citizenship behavior in Greek service organizations: a survey," Employee Relations, vol. 29, pp. 469-491, 2007.

[27] A. F. David and L. T. Thomas, "Job satisfaction and organizational citizenship behavior (OCB): does team commitment make a difference in self-directed teams?," Management Decision, vol. 46, pp. 933-947, 2008.

[28] H. H. Jen, H. J. Bih and Y. Chyan, "Satisfaction with business-to-employee benefits systems and organizational citizenship behavior: An examination of gender differences," International Journal of Manpower, vol. 25, pp. 195-210, 2004.

[29] C. Aaron and K. Yardena, "Professionalism and organizational citizenship behavior: An empirical examination among Israeli nurses," Journal of Managerial Psychology, vol. 19, pp. 386-405, 2004.

[30] B. M. Scott, M. P. Phillip and B. P. Julie, "Do citizenship behaviors matter more for managers than for salespeople?," Academy of Marketing Science, vol. 27, pp. 396-410, 1999.

[31] I. C. Venetta and C. B. Walter, "Investigation the underlying structure of the citizenship performance domain," Human Resource Management Review, vol. 10, pp. 25-44, 2000.

[32] B. C. Carmen, M. A. Enrique and M. R. David, "The influence of employee organizational citizenship behavior on customer loyalty," International Journal of Service Industry Management, vol. 25, pp. $27-53,2004$

[33] L. W. Porter and F. J. Smith, "Title," unpublished.

[34] K. J. Ajay, I. G. Sabir and L. C. Cary, "Employee wellbeing, control and organizational commitment," Leadership \& Organization Development Journal, vol. 30, pp. 256-273, 2009. 